Expl Cell Biol. 1976;44:I-IV

\title{
Contents, Vol. 44, 1976
}

Vol. 44,1976

Experimental Cell Biology

International Journal of

Experimental Pathology, Microbiology and Immunology

(formely 'Pathologia et Microbiologia')

Founded 1938 as 'Schweizerische Zeitschrift für allgemeine Pathologie und Bakte-riologie' by A. v. Albertini, A. Grumbach and H. Mooser, continued as 'Pathologia et Microbiologia'

Editors:

Co-Editors:

Pathology:

J. R. Rüttner, Zurich

G. Zbinden, Zurich M. Kyogoku, Kobe P. Vassalli, Genf R. Hess, Bern M. A. Spycher, Zurich Microbiology:

J. Lindenmann, Zurich

H. Baer, Gainesville, Fla.

I. Gresser, Villejuif

A. Harboe, Oslo

J. Oxford, London

R. Rott, Giessen

R. G. Webster, Memphis,

Tenn. R. Zinkernagel, La Jolla,

Calif. H. Mäkelä, Helsinki

Immunology:

H. Ramseier, Zurich

D. G. Braun, Basel

E. Diener, Edmonton

G. F. Mitchell, Melbourne R. T. Smith, Gainesville,

Fla. J. Sprent, London E. Wecker, Würzburg H. Wigzell, Uppsala

S. Karger · Basel $\cdot$ München · Paris · London · New York · Sydney

All rights reserved.

No part of this publication may be translated into other languages, reproduced or utilized in any form or by any means, electronic or mechanical, including photocopying, recording, microcopying, or by any information storage and retrieval system, without permission in writing from the publisher.

(C) Copyright 1977 by S. Karger AG, 4011 Basel (Switzerland), Arnold-Böcklin-Strasse 25.

Contents

No. 1

Livni, N. and Legum, C: Ultrastructure of Cultured Fibroblasts in Mucolipidosis Type IV 
Kreuter, J.; Mauler, R.; Gruschkau, H., and Speiser, P. P.: The Use of New Polymethylmethacrylate Adjuvants for Split Influenza Vaccines 12 Keusch, F.; Rüttner, J. R.; Pedio, G., and Gut, D.: Occurrence of Plasmocytoid Cells in Long-Term Blood-Cell Cultures from a Patient with 'Hairy Cell' Leukemia 20

Ramseyer, H.: Transplantation Tolerance at the T-Lymphocyte Receptor Level. I. Spontaneous Release of T-Cell Receptors by Lymphocytes from Tolerant Mice 28

Ramseier, H.: Transplantation Tolerance at the T-Lymphocyte Receptor Level. II. Interaction of T-Cell Receptors with Alloantigen and with Anti-Receptor Antiserum 44

No. 2

Reuber, M. D.: Effect of Age and Sex on Lesions of the Esophagus in Buffalo Strain Rats Ingesting Diethylnitrosamine 65 Heath, D.; Smith, P., and Harris, P.: Clara Cells in the Llama 73 Ohkuni, H. and Kimura, Y.: Increased Capillary Permeability in Guinea Pigs and Rats by Peptidoglycan Fraction Extrated from Group A Streptococcal Cell Walls 83

Arnheiter, H; Haller, O., and Lindenmann, J.: Pathology of Influenza Hep atitis in Susceptible and Genetically Resistant Mice 95

Keller, R.; Bregnard, A.; Gehring, W. J., and Schroeder, H. E.: Morpho logic and Molecular Changes in Target Cells during in vitro Interaction with Macrophages 108

No. 3-4

Comoglio, P. M. and Zappacosta, S.: Prefatory Note 129

Appella, E. and Law, L. W.: Histocompatibility Antigens and Tumor-Specific Transplantation Antigens 131

IV

Contents

Comoglio, P. M. and Forni, G.: Molecular Basis of the Immunogenicity of

Cell Surface Tumor Antigens 150

Della Porta, G. and Parmiani, G.: Antigens of Chemically Induced Tumors 170 Alexander, P.: On the Nature of Tumour-Specific Transplantation-Type Anti gens 184

Ehrnst, A. and Sundqvist, K.-G.: The Mechanisms of Appearance of Viral Glycoproteins at the Cell Surface Membrane 198

Hobart, M. J.: Role of Complement Components on Cells and in Cell Inter actions 226

Cogoli, A. and Pearson, T. W.: Intracellular Events in Membrane-Mediated Stimulation of Lymphocytes in vitro 235

Chiarugi, V. P.: Cell-Coat Glycosaminoglycans in Cellular Transformation and Differentiation 251

Tomasi, V.: Prostaglandin E1 as an Intercellular Regulator of Cyclic AMP

Levels 260

Author Index 278

Subject Index 279 
Contents Vol. 44

after 279 